\title{
Upaya Peningkatan Pendapatan Rumah Tangga Melalui Pengembangan Usaha Pada Kelompok Petani Jamur Tiram Desa Pamotan Kabupaten Rembang
}

\author{
Siti Alliyah, Rikah \\ Sekolah Tinggi Ilmu Ekonomi YPPI Rembang \\ wildankafa@yahoo.co.id
}

Submitted: 18 March 2019. Revised: 8 July 2019. Accepted: 27 July 2019

Key word:

Oyster

mushroom;

training;

assistance;

marketing;

bookkeeping

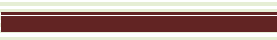

\section{Kata Kunci}

Jamur tiram,

pelatihan;

pendamipingan;

pemasaran;

pembukuan

\begin{abstract}
The Community Service Program was carried out in Pamotan Village, Pamotan sub-district, Rembang Regency with partners from the Hanoman Makmur Group and Rizki Jamur. Pamotan Village is one of the villages in Rembang Regency where several of its residents have traditional oyster mushroom businesses and cultivation and need to get attention as well as assistance. The purpose of this program is to increase the income of the Hanoman Makmur Group and Rizki Jamur. The methodology used is counseling, entrepreneurship management training and practice in making baglogs, and business assistance. The results of this community service program include: 1) the formation of the Mushroom Pamot community which is a communication forum for mushroom farmers; 2) mushroom farmers are able to create mushroom baglog (media) independently; 3) has promotional media such as: brochures, product packaging, banners, blogs and business cards that are used as marketing media; 4) have an orderly and good record keeping.
\end{abstract}

\section{Abstrak}

Program Pengabdian Pada Masyarakat ini dilaksanakan di Desa Pamotan kecamatan Pamotan Kabupaten Rembang dengan mitra Kelompok Hanoman Makmur dan Rizki Jamur. Desa Pamotan merupakan salah satu desa di Kabupaten Rembang yang beberapa warganya memiliki usaha dan budidaya jamur tiram yang masih tradisional dan perlu mendapatkan perhatian juga pendampingan. Tujuan dari program ini adalah untuk meningkatkan pendapatan Kelompok Hanoman Makmur dan Rizki Jamur. Metodologi yang dilakukan adalah penyuluhan, pelatihan manajemen kewirausahaan dan praktek membuat baglog, serta pendampingan usaha. Hasil program pengabdian pada masyarakat ini antara lain: 1) terbentuknya paguyuban Pamot Jamur yang menjadi wadah komunikasi petani jamur; 2) petani jamur sudah mampu membuat baglog (media) jamur secara mandiri; 3) memiliki media promosi seperti: brosur, kemasan produk, banner,blog dan kartu nama yang digunakan sebagai media pemasaran; 4) telah memiliki catatan pembukuan yang tertib dan baik. 


\section{PENDAHULUAN}

Seiring dengan perkembangan berbagai macam kuliner yang ditawarkan kepada masyarakat oleh rumah makan atau catering saat ini menyebabkan permintaan akan produksi sayur-sayuran dan lainnya meningkat, salah satunya adalah jamur tiram. Masyarakat sudah mulai memilih jenis makanan yang bebas dari pencemaran bahan pangan seperti residu pupuk dan pestisida serta tidak mengandung kolesterol. Secara umum, kandungan gizi jamur tiram adalah sebagai berikut protein rata-rata $3,5 \%-4 \%$ dari berat basah. Berarti dua kali lipat lebih tinggi dibandingkan asparagus dan kubis. Jika dihitung berat kering kandungan proteinnya 19 - $35 \%$. Sedangkan beras hanya $7,3 \%$ gandum $13,2 \%$ kedelai $39,1 \%$ susu sapi 25,2\%. Jamur tiram juga mengandung 9 macam asam amino yaitu (1) lisin (2) metionin (3) triptofan (4) threonin (5) valin (6) leusin (7) isoleusin (8) histidin (9) fenil alalanin. Lemak dalam jamur tiram sebesar $72 \%$ asam lemak tidak jenuh, sehingga aman dikonsumsi baik yang menderita kelebihan kolesterol maupun gangguan metabolisme lipid lainnya, sementara sisanya $28 \%$ asam lemak jenuh serta adanya semacam polisakarida kitin di dalam jamur tiram diduga menimbulkan rasa enak (Nasution, 2016).
Jamur tiram tumbuh dan berkembang sepanjang tahun di berbagai iklim tropis dan sub tropis. Di negara yang mempunyai 4 musim, jamur tiram tumbuh baik pada musim panas. Di Indonesia jamur tiram bisa tumbuh saat musim hujan maupun kemarau. Budidaya jamur tiram bisa dilakukan di dalam rumah jamur atau kumbung. Syarat rumah jamur suhu ruangan tidak lebih dari $28^{\circ} \mathrm{C}$ (Suharjo, 2015). Cahaya yang disukai selama pertumbuhan jamur tiram dengan penyinaran tidak langsung. Salah satu desa di Kabupaten Rembang yang memiliki petani jamur adalah desa Pamotan.

Desa Pamotan terletak di Kecamatan Pamotan, Kabupaten Rembang mempunyai luas 1.077.247 Ha. Secara geografis Desa Pamotan di sebelah Utara berbatasan dengan Desa Sumberjo, sebelah Selatan berbatasan dengan Desa Gambiran, sebelah Barat berbatasan dengan Desa Sidorejo, dan sebelah Timur berbatasan dengan Desa Bangunrejo. Jumlah penduduk Desa Pamotan adalah 10.181 jiwa dengan $13 \mathrm{RW}$ dan $42 \mathrm{RT}$, yang sebagian besar penduduknya bekerja di sektor pertanian dan pertukangan (Rembang, 2015). Desa Pamotan terkenal dengan budidaya jamur yang tersebar di 4 dusun, yaitu ; Dusun Kanoman, Dusun Cikalan, Dusun Karangasri dan Dusun Tajen. 


\begin{abstract}
Perkembangan budidaya usaha pembudidayaan jamur saat ini sangat menguntungkan bagi konsumen, karena jamur merupakan makanan yang bergizi tinggi. Kandungan lemaknya yang rendah menyebabkan jamur tiram layak untuk
\end{abstract} dikonsumsi. Jamur tiram yang teksturnya mirip dengan daging ayam merupakan makanan favorit bagi vegetarian. Kandungan nutrisi pada jamur juga terbilang lengkap. Jamur tiram mengandung vitamin penting, terutama vitamin $\mathrm{B}$, vitamin $\mathrm{C}$ dan Vitamin D. Mineral utama tertinggi adalah Kalium, Fosfor, Natrium, Kalsium dan Magnesium (Shifriyah, Badami, \& Suryawati, 2012). Harapannya dengan memperhatikan faktor-faktor penting dalam budidaya jamur ini diharapkan dapat meningkatkan produksi dan kualitas dari jamur tiram serta penanganan pengolahan pasca panen yang tepat dapat meningkatkan nilai jual jamur tiram itu sendiri.

Hasil pra-survei di Desa Pamotan terdapat 6 (enam) kelompok budidaya jamur tiram. Kelompok budidaya jamur tiram tersebut melalui masing-masing ketua kelompok budidaya jamur tiram menyatakan belum mampu membuat baglog sendiri. Kebutuhan baglog selama ini masih dipenuhi dari pelaku usaha jamur tiram dari Solo. Adanya permasalahan tersebut maka produksi jamur tiram masih rendah. Budidaya jamur dilakukan dengan menginokulasi bibit jamur ke dalam media yang biasa disebut baglog. Baglog ini berisi media-media yang diperlukan untuk pertumbuhan jamur seperti apas kayu gergaji, bekatul, kapur tepung jagung dan tepung tapioka (Ginting, Herlina, \& Tyasmoro, 2013).

Tim pengabdi memilih 2 (dua) dari kelompok petani budidaya jamur tiram yang ada, untuk dibina dan didampingi. Kedua kelompok tersebut adalah Hanoman makmur dan Rizki Jamur. Pada awalnya, kelompok tersebut membeli baglog dari daerah Solo Jawa Tengah. Harga baglognya berkisar Rp 1.800,. sampai Rp 2.000,-. Akan tetapi, kualitas baglog yang tidak konsisten menyebabkan banyak baglog yang rusak karena terkontaminasi oleh jamur perusak. Kondisi biaya produksi dan pendapatan yang tidak seimbang mengakibatkan beberapa kali periode kelompok mengalami kerugian. Sementara berdasarkan penghitungan analisis kelayakan usaha, budidaya jamur tiram yang dilakukan di Ciwidey dengan kemampuan membuat baglog sendiri adalah layak menurut beberapa aspek kelayakan (Mitha, Haryono, \& Rosanti, 2015).

Kendala yang dihadapi oleh kelompok mitra dalam membuat baglog adalah modal dan pengetahuan membuat 
media tanam bagi jamur. Selain itu kendala peralatan dan pengetahuan khususnya mengenai manajemen keuangan dalam budidaya jamur tiram masih kurang baik, hal tersebut ditunjukkan dengan belum dilakukannya pembukuan kegiatan maupun keuangan dan pengelolaan keuangan secara baik. Budidaya jamur tiram di desa Pamotan masih belum mempunyai catatan pembukuan keuangan usaha dan pembukuan kegiatan. Selain itu keuangan usaha juga belum dikelola dengan baik, keuangan usaha dengan keuangan keluarga masih bercampur. Pencatatan keuangan dapat dilakukan secara sederhana dari kas masuk dan kas keluar serta penghitungan harga pokok produksi sebagaimana dilakukan oleh pembudidaya jamur tiram di Pekon Tambahrejo, Pringsewu (Yusa \& Magdalena, 2015).

Berdasarkan uraian diatas, permasalahan yang dihadapi oleh kelompok usaha bagi UKM jamur di desa Pamotan yaitu :

1. Tidak bisa memenuhi permintaan pasar jamur tiram karena rendahnya hasil produksi jamur akibat kapasitas produksi yang kurang dan masih cukup banyak baglog yang terkontaminasi jamur.

2. Rendahnya produksi baglog sehingga mengurangi kapasitas produksi
3. Rendahnya penguasaan manajemen waktu dalam menentukan waktu pembibitan agar produksi dapat berkesinambungan

4. Kurangnya modal sehingga menyebabkan petani jamur kesulitan untuk mengembangkan usahanya khususnya untuk memperbaiki kumbung jamur

5. Kurangnya pengetahuan petani jamur dalam membuat produk-produk olahan jamur sehingga tidak dapat menambah nilai jual produk, khususnya jamur yang tidak layak untuk dijual segar.

6. Kurang menguasai manajemen usaha yaitu manajemen pemasaran dan manajemen keuangan sehingga pengelolaan administrasi masih lemah.

7. Belum adanya institusi yang secara intens memberikan pembinaan dalam mengembangkan usaha dan meningkatkan pendapatan petani jamur tiram.

Permasalahan dari mitra baik dari aspek produksi maupun manajemen yang disepakati bersama di atas tidak semuanya dapat diselesaikan dalam pelaksanaan IbM ini. Untuk itu prioritas permasalahan yang disepakati untuk diselesaikan dalam program IbM ini adalah: 
1. Mengoptimalkan peran kelompok budidaya jamur tiram untuk mendorong kelembagaan pembudidaya.

2. Peningkatan kemampuan untuk membuat baglog jamur sendiri, untuk memotong biaya produksi.

3. Memberikan pengetahuan dan pendampingan mengenai manajemen keuangan maupun manajemen pemasaran.

4. Membina dan mendampingi pengembangan usaha untuk meningkatkan pendapatan petani jamur tiram.

\section{METODE}

Metode pendekatan yang dilakukan untuk menyelesaiakan masalah mitra adalah:

1. Memberi penyuluhan, pelatihan dan pendampingan kepada petani jamur mengenai pentingnya/manfaat adanya kelompok dan jejaring petani jamur di Pamotan, Kecamatan Pamotan, Kabupaten Rembang. Memberikan penyuluhan ditujukan untuk memotivasi dan memberi pengetahuan akan pentingnya kelompok kepada anggota kelompok petani jamur agar lebih aktif lagi sehingga jaringan bisa lebih luas dan berkembang. Pelatihan yang dimaksud adalah memberikan pelatihan manajemen dan kewirausahaan kepada anggota kelompok jamur agar memiliki pengetahuan dan kemampuan manajerial dan kewirausahaan dalam mengelola usahanya. Pendampingan usaha dilakukan setelah pelatihan selesai, pendampingan usaha dimaksudkan agar kelompok petani jamur ada motivasi untuk meningkatkan usahanya dan kemampuan manajerialnya meningkat, terutama dalam mempromosikan dan menjual produk serta membukukan transaksi usahanya.

2. Memfasilitasi penguatan peran kelompok petani jamur agar mampu meningkatkan perekonomian petani jamur dan identitas desa sebagai desa wisata.

3. Melakukan pelatihan manajemen dan kewirausahaan, yang mencakup: motivasi berwirausaha, inovasi dan kreativitas, pengelolaan keuangan, manajemen pemasaran, serta praktek membuat media jamur (bag log).

4. Memfasilitasi pengadaan media pemasaran seperti: brosur, banner, kemasan, dan kartu nama agar usaha petani jamur di desa Pamotan bisa lebih dikenal oleh masyarakat luas. 
Dari uraian di atas, maka metodologi pelaksanaan program pengabdian pada masyarakat dapat dibuat skema sebagaimana gambar 1 di bawah ini.

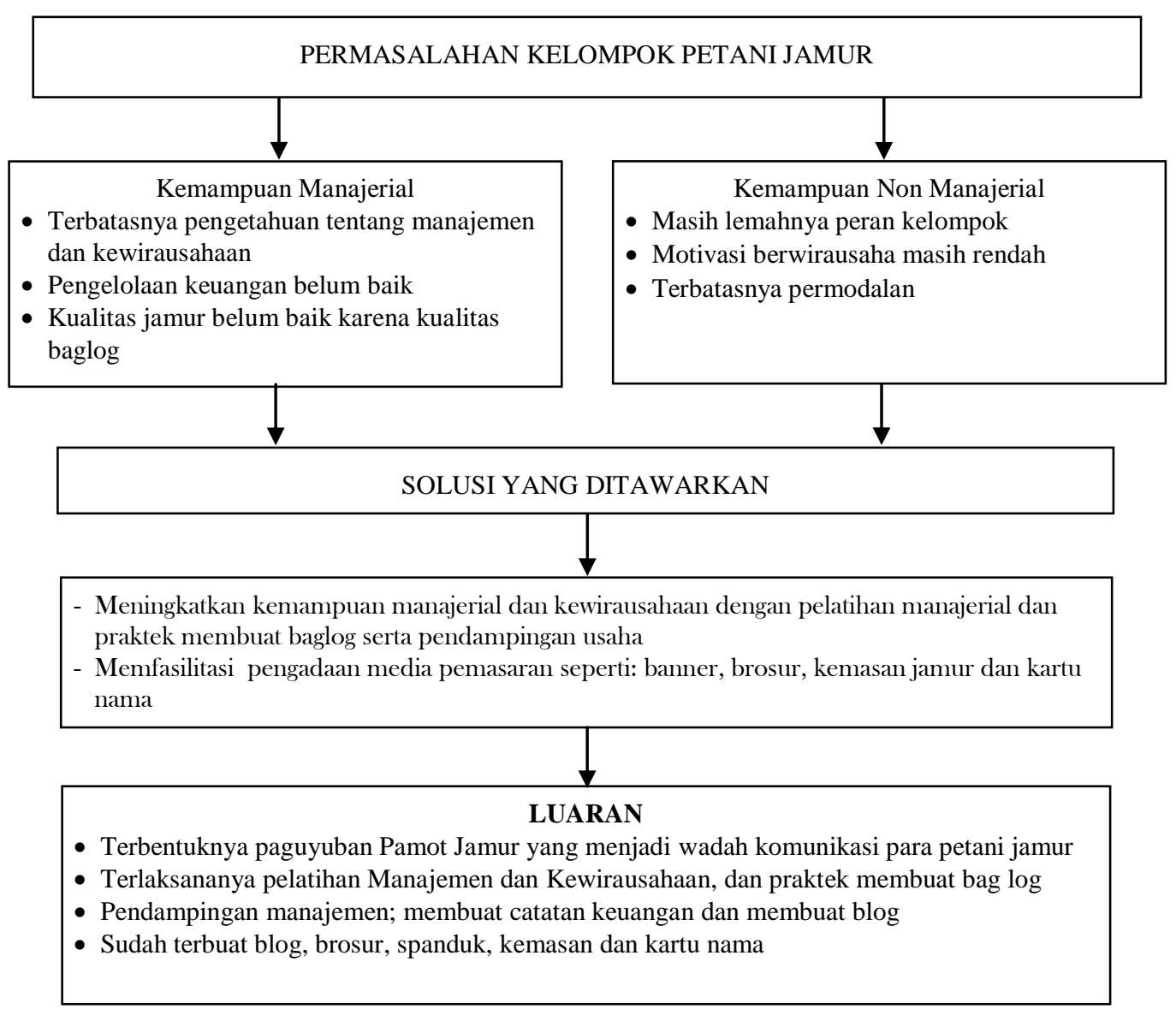

Gambar 1. Metodologi Pelaksanaan Program

HASIL

Pelaksanaan program pengabdian pada masyarakat kelompok Hanoman Makmur dan rizki jamur di desa Pamotan Kecamatan Pamotan Kabupaten Rembang, Tim telah melakukan kegiatan sebagai berikut:
1. Memberikan penyuluhan kepada petani jamur mengenai pentingnya/manfaat adanya kelompok dan jejaring petani jamur di Desa Pamotan, Kecamatan Pamotan, Kabupaten Rembang. Respon dari anggota kelompok petani jamur sangat baik dan penuh semangat. 


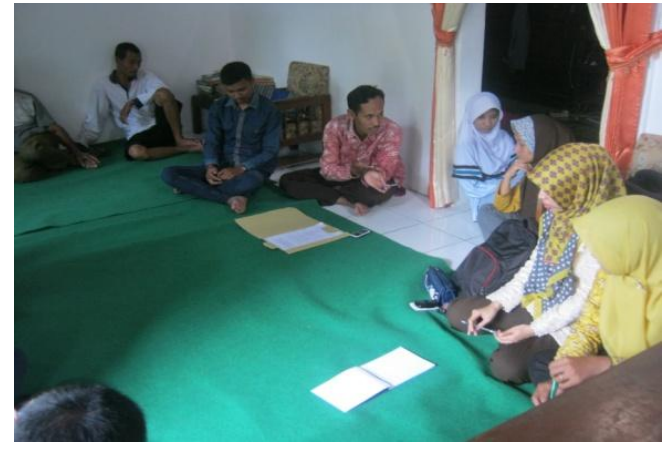

Gambar 1. Penyuluhan paguyuban petani Jamur

2. Melakukan pelatihan Manajemen dan Kewirausahaan dilaksanakan pada tanggal 21 - 22 Juni 2016 dengan materi tentang Motivasi Berwirausaha, Inovasi, Kreativitas, Manajemen Pemasaran, Pengelolaan Keuangan UMKM. Narasumber (konsultan) pelatihan/penyuluhan berasal dari STIE 'YPPI' Rembang yang memiliki kompetensi sesuai dengan bidangnya.

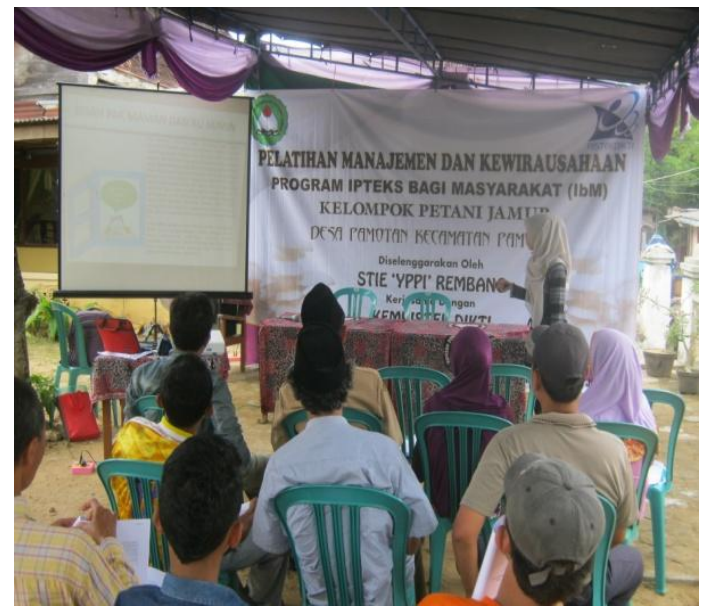

Gambar 2. Pelatihan Manajemen dan Kewirausahaan

3. Pelatihan pembuatan baglog dan praktik pembuatan media tanam jamur. Alat dan bahan pembuatan disediakan oleh STIE YPPI Rembang.

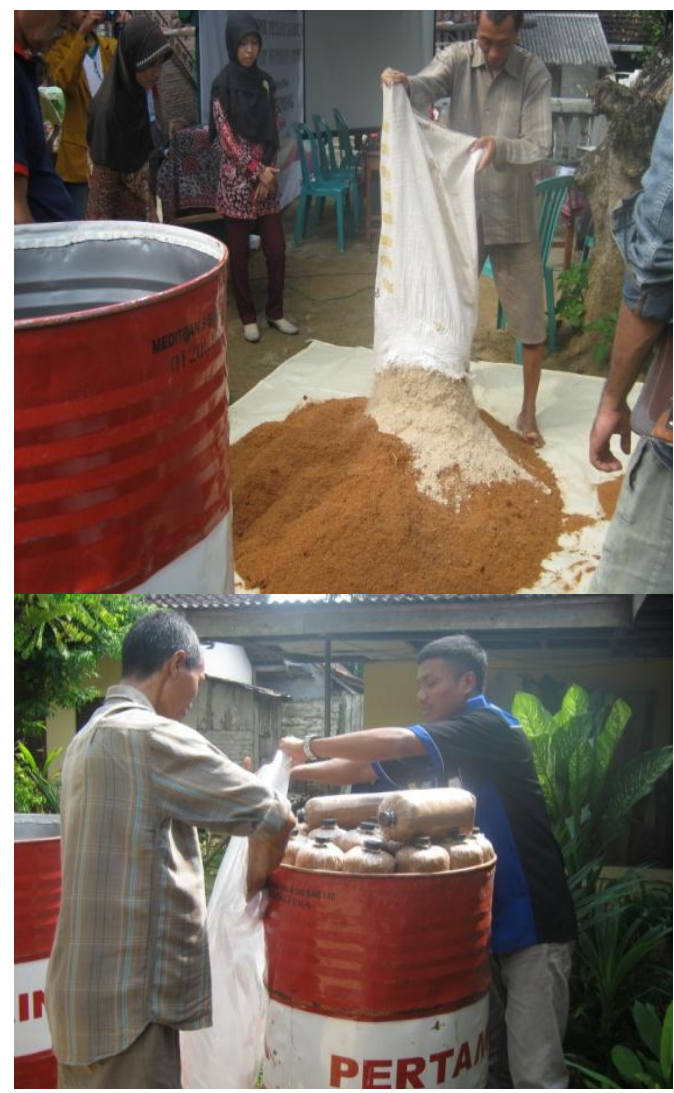

Gambar 3. Pelatihan Pembuatan Baglog Jamur

4. Melakukan pelatihan manajemen keuangan dan manajemen produksi sederhana;

5. Melakukan pendampingan dan monitoring atas kemampuan pembuatan baglog, manajerial keuangan dan produksi, serta perkembangan pertumbuhan jamur menggunakan baglog yang dibuat.

\section{PEMBAHASAN}

Keseluruhan program pengabdian berjalan dengan baik dan disambut 
antusias. Pembahasan masing-masing kegiatan untuk mempertajam kebermanfaatan dan keberhasilan program adalah sebagai berikut:

1. Setelah mengikuti penyuluhan mengenai pentingnya kelembagaan dalam pertanian, anggota kelompok Hanoman Makmur dan Rizki Jamur bisa memahami pentingnya peran kelompok dalam memajukan usaha. Sebagai tindak lanjut dari kegiatan ini terbentuklah satu paguyuban yang akan mewadahi permasalahan petani jamur. Tepatnya pada Sabtu, 2 Juli 2016 terbentuk sebuah paguyuban petani jamur dengan nama "Pamot Jamur". Sebagaimana hasil pengabdian dan penelitian mengenai kelembagaan pertanian di mana kelompok tani budidaya yang kuat akan memberikan bargaining position dan memiliki dampak positif dalam pengembangan usaha (Iriantinah, 2014). Paguyuban "Pamor Jamur" juga telah menyusun Visi dan Misi kegiatan dapat berjalan terarah.

2. Kegiatan pelatihan Manajemen dan Kewirausahaan dilaksanakan pada tanggal 21 - 22 Juni 2016 dengan materi tentang Motivasi Berwirausaha, Inovasi, Kreativitas, Manajemen Pemasaran, Pengelolaan Keuangan UMKM. Narasumber (konsultan) pelatihan/penyuluhan berasal dari STIE 'YPPI' Rembang yang memiliki kompetensi sesuai dengan bidangnya. Narasumber telah berpengalaman dalam pendampingan usaha UMKM. Peserta dalam pelatihan Manajemen dan Kewirausahaan program ini adalah anggota kelompok Hanoman Makmur dan Rizki Jamur yang berjumlah 10 orang. Peserta adalah anggota kelompok yang sedang merintis usaha. Pelatihan manajemen dan kewirausahaan ini dilaksanakan dengan tujuan untuk meningkatkan kemampuan manajerial kelompok petani jamur.

3. Pelatihan dan praktek membuat baglog diikuti oleh 10 anggota paguyuban. Teori utama yang disampaikan adalah penggunaan kayu berjenis lunak dan disarankan dari satu jenis (serbuk) kayu sebagai bahan utama pembuat baglog (Ginting dkk., 2013). Peserta mampu membuat 488 baglog. Baglog yang telah siap kemudian dikukus dengan menggunakan 2 (dua) drum. Hari berikutnya, baglog yang telah dikukus kemudian dikeluarkan dari drum dan diberi bibit F2, kemudian baglog yang telah diberi bibit F2 dimasukkan ke dalam kumbung jamur.

4. Pendampingan manajemen usaha dilakukan sebanyak 3 (tiga) kali setelah kegiatan pelatihan manajemen dan 
kewirausahaan. Selama sekitar satu bulan dilakukan pendampingan manajemen usaha khususnya dalam pencatatan keuangan usaha. Selama proses pendampingan kelompok petani jamur masih belum tertib untuk melakukan pencatatan. Kurang tertibnya kelompok dalam melakukan pencatatan administrasi dan pembukuan dapat menjadi salah satu faktor tidak berkembangnya usaha baik (Arminsyurita, 2014). Kondisi ini yang menjadi perhatian dari tim pengabdi untuk terus memberikan pendampingan dan memberikan motivasi agar paguyuban dapat berkembang lebih baik.

5. Selain pendampingan manajemen usaha juga dilakukan pemantauan terkait perkembangan jamur hasil dari baglog pelatihan. Bulan pertama baglog yang telah dibuat, banyak yang telah tumbuh spora, bahkan ada yang telah tumbuh jamur. Hal ini ini mengindikasikan bahwa baglog yang telah dibuat peserta dan pembibitan yang dilakukan telah sesuai dengan daya tumbuh rata-rata (Kalsum, Fatimah, \& Wasonowati, 2011). Pada bulan ketiga baglog ini juga masih dapat digunakan sebagai media tanam.

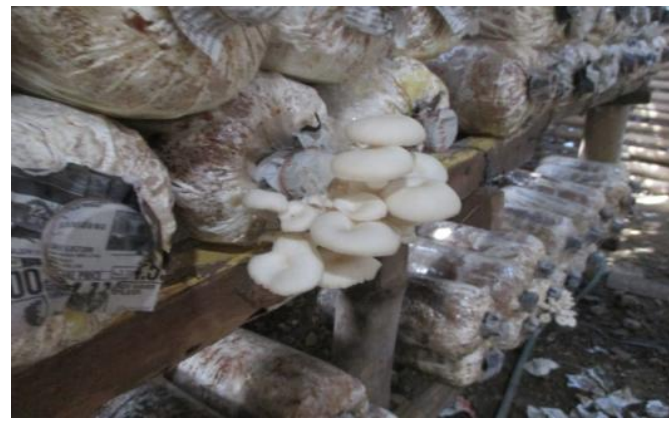

Gambar 4. Baglog yang tumbuh jamur

6. Pendampingan manajemen usaha, khususnya dalam pemasaran yang dilakukan menghasilkan menghasilkan web blog kelompok jamur, brosur, dan kartu nama. Namun dari pembuatan blog kelompok tersebut petani jamur belum secara maksimal memanfaatkan blog tersebut. Sehingga pemanfaatan media online belum secara maksimal mempengaruhi pendapatan kelompok petani jamur. Petani jamur lebih tertarik untuk memanfaatkan media pemasaran secara konvensional seperti brosur dan kartu nama. Brosur dan kartu nama ini juga digunakan penyebaran informasi mengenai paguyuban dan produk jamur tiram ke calon pembeli potensial seperti restoran dan pedagang pasar. 


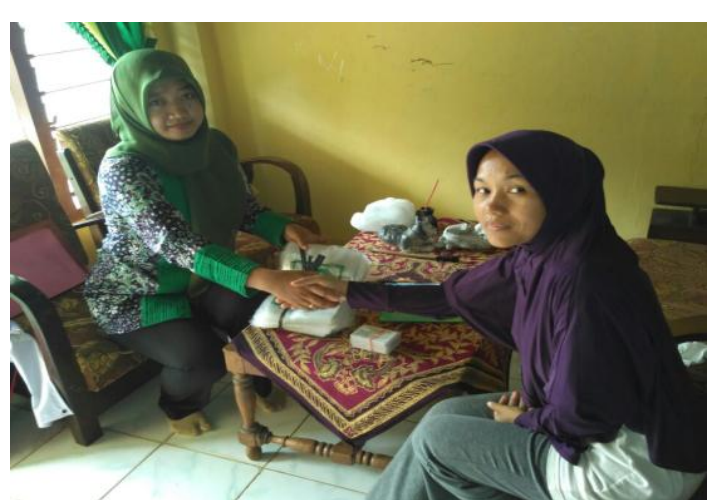

Gambar 5. Penyerahan media pemasaran berupa kartu nama, brosur dan kemasan

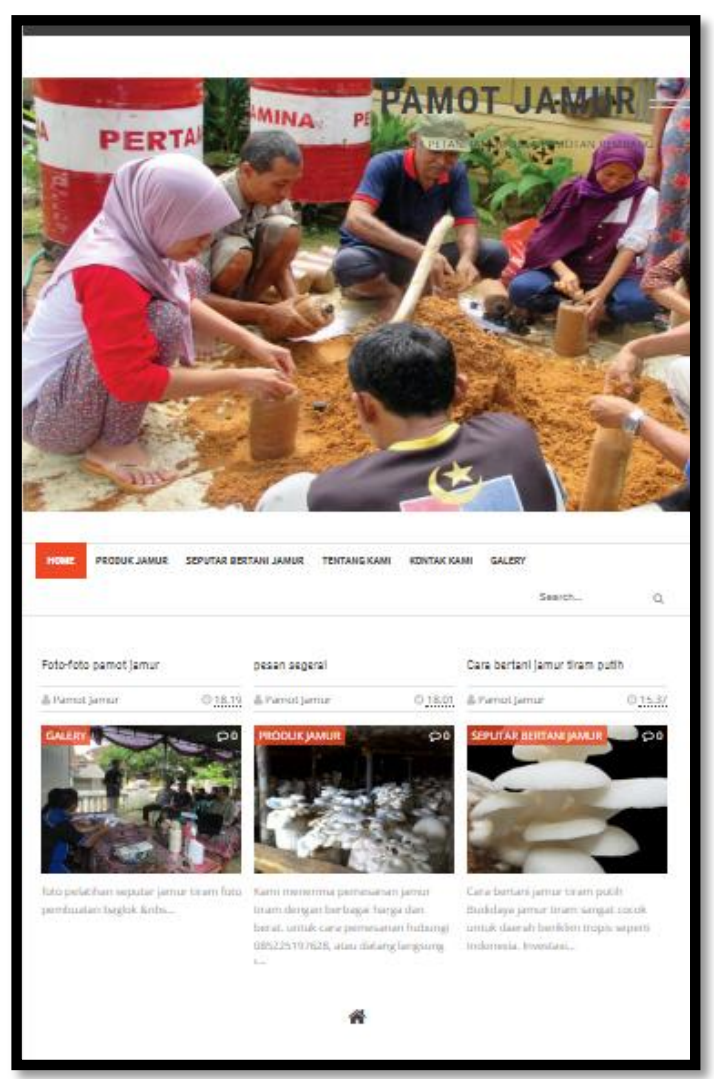

Gambar 6. Blog kelompok petani jamur http://pamotjamur.blogspot.com

\section{KESIMPULAN}

Hasil dari program pengabdian pada masyarakat Kelompok Petani Jamur di Desa Pamotan Kecamatan Pamotan sebagai berikut:
1. Kegiatan penyuluhan tentang pentingnya paguyuban dalam usaha jamur tiram telah ditindaklanjuti oleh petani jamur dengan membuat paguyuban "Pamot Jamur", sekaligus terbentuk struktur organisasi, visi dan misi.

2. Pelatihan manajemen dan kewirausahaan selama tiga hari dengan materi motivasi berwirausaha, inovasi, kreativitas, manajemen pemasaran, praktek membuat baglog. Pelatihan manajemen dan kewirausahaan ini dilaksanakan dengan tujuan untuk meningkatkan kemampuan manajerial kelompok petani jamur

3. Untuk menjaga keberlanjutan program, maka dilakukan pendampingan manajemen usaha terutama dalam manajemen pemasaran dan manajemen keuangan. Adapun dari hasil pendampingan selama tiga kali, kelompok petani jamur sudah bisa membuat baglog sendiri dan telah mampu membuat pencatatan keuangan yang tertib.

4. Untuk memperlihatkan kepada konsumen terhadap jamur tiram yang dihasilkan oleh petani jamur yang tergabung dalam Paguyuban Pamot Jamur, maka Tim pengabdian pada masyarakat membuatkan kemasan jamur, selain itu meningkatkan 
penjualan jamur tiram Tim

membuatkan banner, brosur dan kartu nama.

5. Praktek membuat olahan jamur dimaksudkan agar petani jamur bisa memanfaatkan jamur yang kualitasnya rendah dengan merubahnya menjadi olahan makanan ringan agar tetap bernilai jual tinggi.

6. Untuk memajukan petani jamur dan meningkatkan pendapatan petani jamur khususnya kelompok petani jamur di desa Pamotan, perlu mendapat kan perhatian khusus dari semua pihak terutama Pemerintah Kabupaten Rembang agar desa Pamotan mampu dan bisa disebut sebagai desa wisata jamur tiram.

\section{SARAN}

Dari kesimpulan tersebut di atas, maka tim memberikan beberapa masukan saran agar kelompok petani jamur di Desa Pamotan Kecamatan Pamotan dapat berkembang lebih baik lagi, antara lain:

1. Setiap anggota kelompok agar berperan lebih aktif lagi dan dapat membentuk jejaring yang lebih luas, baik dalam hal inovasi produk maupun pemasaran produk.

2. Kemasan dan label yang sudah ada agar bisa dipergunakan sebagaimana mestinya terutama bila ada pembeli. Hal ini supaya kualitas jamur terjamin dan terlihat bersih.

3. Harapannya setelah program pengabdian pada masyarakat ini selesai, kelompok petani jamur bisa melanjutkan pencatatan keuangannya secara tertib dan berkelanjutan.

\section{UCAPAN TERIMA KASIH}

Selesainya pelaksanaan program pengabdian pada masyarakat di Desa Pamotan Kecamatan Pamotan Kabupaten Rembang tidak terlepas dari kerjasama yang terjalin dengan berbagai pihak. Kami mengucapkan terima kasih kepada semua pihak yang telah bekerjasama dan membantu terlaksananya program pengabdian pada masyarakat Kelompok Petani jamur ini yang tidak bisa disebut satu per satu. Ucapan terima kasih terutama ditujukan kepada:

1. Kementerian Riset, Teknologi, dan Pendidikan Tinggi, Direktorat Jenderal Pembelajaran dan Kemahasiswaan khususnya Direktorat Riset dan Pengabdian Masyarakat yang telah mendanai pelaksanaan program pengabdian ini.

2. Kopertis Wilayah VI Jawa tengah yang telah mengkoordinir dan memfasilitasi 
pelaksanaan pengabdian kepada masyarakat ini.

3. Lembaga Penelitian dan Pengabdian kepada Masyarakat STIE 'YPPI' Rembang yang telah mengkoordinir terlaksananya program pengabdian ini.

4. Kelompok Hanoman Makmur dan Rizki Jamur yang telah bersedia untuk menjadi mitra dalam pelaksanaan program pengabdian ini.

\section{DAFTAR PUSTAKA}

Arminsyurita, A. (2014). Analisis Strategi Pemasaran Jamur Rimba Jaya Mushroom. Transparansi Jurnal Ilmiah Ilmu Administrasi, 6(2), 156-168.

https://doi.org/10.31334/trans.v6i2. 39

Ginting, A. R., Herlina, N., \& Tyasmoro, S. Y. (2013). Studi Pertumbuhan dan Produksi Jamur Tiram Putih (Pleorotus Ostreatus) Pada Media Tumbuh Gergaji Kayu Sengon dan Bagas Tebu. Jurnal Produksi Tanaman, 1(2). https://doi.org/10.21176/protan.v1i 2.14

Iriantinah, C. (2014). Strategi Pengembangan Komoditas Jamur Tiram Putih (Pleurotus Florida) Di Kabupaten Nganjuk. Jurnal
Manajemen Agribisnis, 14(2), 161172.

Kalsum, U., Fatimah, S., \& Wasonowati, C. (2011). Efektivitas Pemberian Air Leri terhadap Pertumbuhan dan Hasil Jamur Tiram Putih (Pleurotus ostreatus). Agrovigor: Jurnal Agroekoteknologi, 4(2), 86-92. https://doi.org/10.21107/agrovigor. v4i2.297

Mitha, S. D., Haryono, D., \& Rosanti, N. (2015). Analisis Pendapatan dan Kesehjahteraan Produsen Jamur Tiram di Kota Metro. Jurnal IlmuIlmu Agribisnis, $3(2)$. https://doi.org/10.23960/jiia.v3i2.\% $\mathrm{p}$

Nasution, J. (2016). Kandungan Karbohidrat dan Protein Jamur Tiram Putih (Pleurotus ostreatus) pada Media Tanam Serbuk kayu Kemiri (Aleurites moluccana) dan Serbuk Kayu Campuran. Eksakta : Jurnal Penelitian dan Pembelajaran MIPA, 1(1). https://doi.org/10.31604/eksakta.v1 i1.\%p

Rembang, B. P. S. K. (2015). Rembang Dalam Angka. Kabupaten Rembang: Badan Pusat Statistik Kabupaten Rembang, 3-23.

Shifriyah, A., Badami, K., \& Suryawati, S. (2012). Pertumbuhan dan Produksi 
Jamur Tiram Putih (Pleurotus

ostreatus) Pada Penambahan Dua

Sumber Nutrisi. Agrovigor: Jurnal

Agroekoteknologi, 5(1), 8-13.

https://doi.org/10.21107/agrovigor.

v5i1.303

Suharjo, E. (2015). Budi Daya Jamur

Tiram Media Kardus. AgroMedia.

Yusa, viola D., \& Magdalena, B. (2015).

Pemanfaatan dan Pengembangan

Desa Berbasis Web dan

Pengembangan Bisnis Budidaya

Jamur Tiram Menjadi Bakso Jamur

di Pekon Tambah Rejo Kec Gading

Rejo Kab Pringsewu. Jurnal

Teknologi Informasi Dan Bisnis

Pengabdian Masyarakat

Darmajaya, 1(2), 57-73. Diambil

dari

https://jurnal.darmajaya.ac.id/index

.php/jbpmd/article/view/812 